\title{
PENERAPAN BATAS-BATAS WANPRESTASI DAN PERBUATAN MELAWAN HUKUM DALAM PERJANJIAN
}

\author{
Sedyo Prayogo \\ Advokat \\ sedyo_prayogo@yahoo.com
}

\begin{abstract}
The Act of the Civil Law makes a clear distinction between the engagement that is born of the agreement and engagement that is born of the legislation. The legal consequences are born of an engagement agreement is desired by the parties, because memng agreement based on the agreement that a rapprochement between the parties will make arrangements. While the legal consequences of an engagement that is born of a statute may not be desired by the parties, but the relationship of law and the legal consequences prescribed by law. Legal issues that arise in case there is a contractual relationship between the parties and the event of default can filed a lawsuit against the law. Based on the identification and analysis, the authors conclude that the draft Civil Code distinguishes between tort lawsuit is based on the contractual relationship between the Plaintiff and the Defendant and tort claims where there is no contractual relationship between the Plaintiff and the Defendant. Developments in the practice of court decisions indicate that a shift in the theory because of the contractual relationship between the Plaintiff and Defendant did not preclude the filing of a lawsuit against the law.
\end{abstract}

Key Word: Stangnant Payment, Act Against The Law, Agreement

\begin{abstract}
Abstrak
Kitab Undang-Undang Hukum Perdata membedakan dengan jelas antara perikatan yang lahir dari perjanjian dan perikatan yang lahir dari undang-undang. Akibat hukum suatu perikatan yang lahir dari perjanjian memang dikehendaki oleh para pihak, karena memng perjanjian didasarkan atas kesepakatan yaitu persesuaian kehendak antara para pihak yang membuat perjanjian. Sedangkan akibat hukum suatu perikatan yang lahir dari undang-undang mungkin tidak dikehendaki oleh para pihak, tetapi hubungan hukum dan akibat hukumnya ditentukan oleh undang-undang. Permasalahan hukum yang timbul adalah dalam hal ada hubungan kontraktual antara para pihak dan terjadi wanprestasi dapatkah diajukan gugatan perbuatan melawan hukum. Berdasarkan identifikasi dan analisis, penulis berkesimpulan bahwa Kitab Undang-Undang Hukum Perdata membedakan antara gugatan wanprestasi yang didasarkan pada hubungan kontraktual antara Penggugat dan Tergugat dan gugatan perbuatan melawan hukum di mana tidak ada hubungan kontraktual antara Penggugat dan Tergugat. Perkembangan dalam praktik putusan-putusan pengadilan menunjukkan bahwa terjadi pergeseran teori tersebut karena hubungan kontraktual antara Penggugat dan Tergugat tidak menghalangi diajukannya gugatan perbuatan melawan hukum.
\end{abstract}

Kata kunci: Wanprestasi, Perbuatan Melawan Hukum, Perjanjian 


\section{A. PENDAHULUAN}

Pasal 1365 Kitab Undang-Undang Hukum Perdata menentukan bahwa tiap perbuatan melawan hukum yang mengakibatkan kerugian pada orang lain, mewajibkan orang yang melakukan perbuatan tersebut untuk mengganti kerugian. ${ }^{1}$ Mariam Darus Badrulzaman dalam Rancangan UU (RUU) Perikatan berusaha merumuskannya secara lengkap, sebagai berikut: ${ }^{2}$

1. Suatu perbuatan melawan hukum yang mengakibatkan kerugian kepada orang lain, mewajibkan orang yang karena kesalahan atau kelalaiannya menebritkan kerugian itu mengganti kerugian tersebut.

2. Melanggar hukum adalah tiap perbuatan yang melanggar hak orang lain atau bertentangan dengan kepatutan yang harus diindahkan dalam pergaulan kemasyarakatan terhadap pribadi atau harta benda orang lain

3. Seorang yang sengaja tidak melakukan suatu perbuatan yang wajib dilakukannya, disamakan dengan seorang yang melakukan suatu perbuatan terlarang dan karenanya melanggar hukum.

Perumusan norma dalam konsep Mariam Darus Badrulzaman ini telah mengabsorbsi perkembangan pemikiran yang baru mengenai perbuatan melawan hukum. Sebab dalam konsep itu pengertian melawan hukum menjadi tidak hanya diartikan sebagai melawan undang-undang (hukum tertulis) tetapi juga bertentangan dengan kepatutan yang harus diindahkan dalam pergaulan masyarakat (hukum tidak tertulis). Perbuatan melawan hukum dalam Pasal 1365 Kitab Undang-Undang Hukum Perdata pawa awalnya memang mengandung pengertian yang sempit sebagai pengaruh dari ajaran

1 R. Subekti dan Tjitrosudibio, 2006, Kitab UndangUndang Hukum Perdata, PT.Pradnya Paramita, Jakarta, hlm.346.

2 Sutan Remy Sjahdeini, dkk, 2007, Naskah Akademis Peraturan Perundang-Undangan tentang Perbuatan Melawan Hukum, Badan Pembinaan Hukum Nasional, Departemen Kehakiman RI, Jakarta, hIm. 18 legisme. Pengertian yang dianut adalah bahwa perbuatan melawan hukum merupakan perbuatan yang bertentangan dengan hak dan kewajiban hukum menurut undnagundang. Dengan kata lain bahwa perbuatan melawan hukum (onrechtmatigedaad) sama sengan perbuatan melawan undang-undang (onwetmatigedaad). ${ }^{3}$

Penilaian mengenai apakah suatu perbuatan termasuk perbuatan melawan hukum, tidak cukup apabila hanya didasarkan pada pelanggaran terhadap kaidah hukum, tetapi perbuatan tersebut harus juga dinilai dari sudut pandang kepatutan. Fakta bahwa seseorang telah melakukan pelanggaran terhadap suatu kaidah hukum dapat menjadi faktor pertimbangan untuk menilai apakah perbuatan yang menimbulkan kerugian tadi sesuai atau tidak dengan kepatutan yang seharusnya dimiliki seseorang dalam pergaulan dengan sesama warga masyarakat. ${ }^{4}$

Terminologi dari "Perbuatan Melawan Hukum" merupakan terjemahan dari kata onrechtmatigedaad, yang diatur dalam Kitab Undang-Undang Hukum Perdata Buku III tentang Perikatan, Pasal 1365 sampai dengan Pasal 1380. Beberapa sarjana ada yang mempergunakan istilah "melanggar" dan ada yang mempergunakan istilah "melawan". Wirjono Prodjodikoro menggunakan istilah "perbuatan melanggar hukum", dengan mengatakan: "Istilah onrechtmatigedaad dalam bahasa Belanda lazimnya mempunyai arti yang sempit, yaitu arti yang dipakai dalam Pasal 1365 Burgerlijk Wetboek dan yang hanya berhubungan dengan penafsiran dari pasal tersebut, sedang kini istilah perbuatan melanggar hukum ditujukan kepada hukum yang pada umumnya berlaku di Indonesia dan yang sebagian terbesar merupakan Hukum Adat". ${ }^{5}$ Subekti juga menggunkan istilah Perbuatan Melanggar Hukum. ${ }^{6}$

3 Rosa Agustina, 2008, Perbuatan Melawan Hukum, FH Universitas Indonesia, Jakarta, hlm. 5

4 Setiawan, 2006, Empat Kriteria Perbuatan Melanggar Hukum dan Perkembangannya Dalam Yurisprudensi, Varia Peradilan No. 16, Desember 2006

5 Wirjono Prodjodikoro, 2008, Perbuatan Melanggar Hukum, Sumur Bandung, Bandung, hlm. 7

6 R. Subekti dan Tjitrosudibio, 2006, Op. Cit, hlm. 346 
Terminologi "Perbuatan Melawan Hukum" antara lain digunakan oleh Mariam Darus Badrulzaman, dengan mengatakan: "Pasal 1365 Kitab Undang-Undang Hukum Perdata menentukan bahwa setiap perbuatan yang melawan hukum yang membawa kerugian kepada seseorang lain mewajibkan orang karena salahnya menerbitkan kerugian ini mengganti kerugian tersebut". ${ }^{7}$

Sri Soedewi Masjchoen Sofwan ${ }^{8}$ dan IS Adiwimarta ${ }^{9}$ dalam menerjemahkan buku H.F.A. Vollmar juga mempergunakan istilah perbuatan melawan hukum. Selain itu, istilah yang sama juga digunakan oleh MA Moegni Djojodirdjo ${ }^{10}$ dan Setiawan..$^{11} \mathrm{MA}$ Moegni Djojodirdjo mengatakan:

"Pasal 1365 Kitab Undang-Undang Hukum Perdata tidaklah memberikan perumusan melainkan hanya mengatur bilakah seseorang yang mengalami kerugian karena perbuatan melawan hukum, yang dilakukan oleh orang lain terhadap dirinya, akan dapat mengajukan tuntutan ganti kerugian pada Pengadilan Negeri dengan succes".

Berdasarkan rumusan di atas maka dapat dikatakan bahwa perbuatan melawan hukum adalah perbuatan yang melanggar hak (subyektif) orang lain atau perbuatan (atau tidak berbuat) yang bertentangan dengan kewajiban menurut undang-undang atau bertentangan dengan apa yang menurut hukum tidak tertulis yang seharusnya dijalankan oleh seorang dalam pergaulannya dengan sesama warga masyarakat dengan mengingat adanya alasan pembenar menurut hukum.

Permasalahan hukum yang timbul adalah dalam hal ada hubungan kontraktual

7 Mariam Darus Badrulzaman, 2006, KUH Perdata Buku III, HUkum Perikatan Dengan Penjelasan, Alumni, Bandung, hlm. 146

8 Sri Soedewi Masjchoen Sofwan, 2010, Hukum Perutangan, Seksi Hukum Perdata Fakultas Hukum UGM, Yogyakarta, hlm. 55

9 H.F.A. Vollmar, 2007, Pengantar Studi Hukum Perdata Jilid II, CV.Rajawali, Jakarta, hlm. 183

10 MA Moegni Djojodirjo, 2009, Perbuatan Melawan Hukum, Jakarta, Pradnya Paramita, Jakarta, hlm. 17

11 Rachmat Setiawan, 2007, Tinjauan Elementer Perbuatan Melawan Hukum, Alumni, Bandung, hlm. 8 antara para pihak dan terjadi wanprestasi dapatkah diajukan gugatan perbuatan melawan hukum.

\section{B. PEMBAHASAN}

1. Penerapan Penerapan Batas-batas Wanprestasi Dan Perbuatan Melawan Hukum Dalam Perjanjian.

Pasal 1233 Kitab Undang-Undang Hukum Perdata menyebutkan sumber perikatan adalah perjanjian dan undangundang. Perikatakn adalah suatu hubungan hukum di bidang hukum kekayaan di mana satu pihak berhak menuntut suatu prestasi dan pihak lainnya berkewajiban untuk melaksanakan suatu prestasi. Sedangkan perjanjian menurut Pasal 1313 Kitab Undang-Undang Hukum Perdata adalah suatu perbuatan dengan mana satu orang atau lebih mengikatkan dirinya terhadap satu orang atau lebih. Definisi ini mendapat kritik dari Prof. R. Subekti, karena hanya meliputi perjanjian sepihak padahal perjanjian pada umumnya bersifat timbal balik, seperti perjanjian jual beli, perjanjian sewa menyewa, perjanjian tukar menukar dan sebagainya. Sedangkan perikatan yang lahir dari undang-undang terdiri atas perikatan yang lahir dari undangundang saja dan perikatan yang lahir dari undang-undang yang berhubungan dengan perbuatan manusia. Perikatan yang lahir dari undang-undang yang berhubungan dengan perbuatan manusia dapat dibagi atas perikatan yang halal dan perikatan yang tidak halal, yaitu perbuatan melawan hukum. ${ }^{12}$

Perikatan yang lahir dari undangundang saja, misalnya adalah hak dan kewajiban antara pemilik pekarangan yang bertetangga. Pasal 667 Kitab UndangUndang Hukum Perdata menyebutkan bahwa pemilik sebidang tanah atau pekarangan yang letaknya terjepit di antara tanah milik orang lain sehingga dia tidak mempunyai jalan keluar, berhak menuntut tetangganya untuk memberi jalan

12 R. Subekti, 2008, Hukum Perjanjian, PT.Intermassa, Jakarta, hlm. 42 
melalui pekarangan milik tetangganya dengan membayar ganti rugi, meskipun di antara mereka tidak ada perjanjian untuk itu. Dengan dicabutnya ketentuan Buku II Kitab Undang-Undang Hukum Perdata oleh Undang-Undang tentang PokokPokok Agraria No. 5 Tahun 1960, maka ketentuan Pasal 667 Kitab Undang-Undang Hukum Perdata tidak berlaku lagi. Jika terjadi sengketa antara para pihak yang mempunyai pekarangan atau tanah yang letaknya bertetangga, maka perlindungan hukum diserahkan kepada hakim dengan mengacu kepada asas bahwa hak milik atas tanah berfungsi sosial.

Selanjutnya perikatan yang lahir dari undang-undang dan berhubungan dengan perbuatan manusia adalah Perwakilan Sukarela yang diatur dalam Pasal 1354 Kitab Undang-Undang Hukum Perdata dan Pembayaran Tidak Wajib yang diatur dalam Pasal 1359 ayat (1) Kitab UndangUndang Hukum Perdata. Perwakilan sukarela terjadi jika seseoran tanpa diminta secara sukarela mewakili kepentingan orang lain. Maka demi hukum orang ini harus menyelesaikan urusan orang yang diwakilinya sampai orang yang diwakilinya dapat mengurus kepentingannya sendiri. Pihak yang telah mewakili orang lain tanpa mendapat perintah, tidak berhak atas upah, akan tetapi dia berhak memperoleh ganti rugi atas segala pengeluaran yang bermanfaat bagi pengurusan tersebut. Demikian bunyi ketentuan Pasal 1357 dan Pasal 1358 Kitab Undang-Undang Hukum Perdata. Selanjutnya Pasal 1359 ayat (1) Kitab Undang-Undang Hukum Perdata menyebutkan bahwa orang yang melakukan pembayaran karena mengira adanya utang padahal tidak ada, maka ia berhak untuk menuntut kembali pembayaran yang tidak diwajibkan itu. Pasal 1359 ayat (1) ini berbeda dengan ketentuan Pasal 1359 ayat (2) Kitab Undang-Undang Hukum Perdata yang menyebutkan bahwa perikatan bebas (naturlijk verbintenis) yang dipenuhi secara sukarela, maka tidak dapat dilakukan penuntutan kembali. Perikatan bebas atau perikatan alam adalah perikatan yang tidak dapat dituntut secara hukum untuk dilaksanakan. Misalnya, utang yang timbul dari perjudian atau seseorang yang sudah dinyatakan pailit berjanji untuk memenuhi sisa utang yang belum dibayarnya dari hasil penjualan harta bendanya. Akan tetapi, jika perikatan itu dipenuhi secara sukarela, maka pembayaran yang dilakukan secara sukarela tersebut tidak dapat diminta kembali.

Sedangkan mengenai perbuatan yang tidak halal diatur dalam Pasal 1365 Kitab Undang-Undang Hukum Perdata tentang perbuatan melawan hukum (onrechtmatigedaad). Pasal 1365 Kitab Undang-Undang Hukum Perdata mewajibkan orang yang melakukan perbuatan melawan hukum dan karena kesalahannya merugikan orang lain, untuk memberikan ganti rugi. Untuk mengajukan gugatan perbuatan melawan hukum, tidak perlu adanya hubungan kontraktual antara pihak yang dirugikan dan pihak yang menimbulkan kerugian.

\section{Ingkar Janji (Wanprestasi)}

Apakah wujud dari tidak memenuhi perikatan itu. Wujud dari tidak memenuhi perikatan itu ada 3 (tiga) macam, yaitu: ${ }^{13}$

a. Debitur sama sekali tidak memenuhi perikatan

b. Debitur terlambat memenuhi perikatan

c. Debitur keliru atau tidak pantas memenuhi perikatan.

Di dalam kenyataan sukar untuk menentukan saat debitur dikatakan tidak memenuhi perikatan, karena sering kali ketika mengadakan perjanjian pihakpihak tidak menentukan waktu untuk melaksanakan perjanjian tersebut. Bahkan di dalam perikatan di mana waktu untuk malsakanakan prestasi itupun ditentukan, cidera janji tidak terjadi dengan sendirinya. Yang mudah untuk menentukan saat debitur tidak memenuhi perikatan ialah pada perikatan untuk tidak berbuat sesuatu.

13 Mariam Darus Badrulzaman, et.al., 2011, Kompilasi Hukum Perikatan, PT.Citra Aditya Bakti, Bandung, hlm. 18 
Apabila orang itu melakukan perbuatan yang dilarang tersebut maka ia tidak memenuhi perikatan.

Akibat yang sangat penting dari tidak dipenuhinya perikatan ialah bahwa kreditur dapat minta ganti rugi atas ongkos, rugi dan bunga yang dideritanya. Untuk adanya kewajiban ganti rugi bagi debitur, maka undnag-undang menentukan bahwa debitur harus terlebih dahulu dinyatakan berada dalam keadaan lalai (ingebrekestelling).

Apabila debitur keliru melakukan prestasi dan kelirunya itu adalah dengan itikad baik, maka pernyataan lalai diperlukan, tetapi kalau kelirunya itu terjadi dengan itikad jahat, maka di sini tidak perlu lagi pernyataan lalai. Pun lembaga itu tiak diperlukan apabila peringatan diadakan untuk jangka waktu tertentu, oleh karena dengan dilampauinya waktu itu, maka berarti debitur telah tidak memenuhi perikatan.

Apakah peringatan/pernyataan lalai perlu untuk perikatan yang tidak dipenuhi pada waktunya? Jawabnya adalah perlu, karena di sini debitur sebenarnya, masih bersedia memenuhi prestasi, hanya saja terlambat. Dengan lembaga itu, debitur masih diberikan kesempatan untuk memenuhi perikatan.

Apabila debitur tidak memenuhi perikatannya (wanprestasi) ataupun pada perikatan-perikatan di mana pernyataan lalai tidak disampaikan kepada debitur, tetapi tidak diindahkannya, maka debitur dikatakan tidak memenuhi perikatan. Hakhak kreditur adalah sebagai berikut: ${ }^{14}$

a. Hak menuntut pemenuhan perikatan (nakomen);

b. Hak menuntut pemutusan perikatan atau apabila perikatan itu bersifat timbal balik, menuntut pembatalan perikatan (ontbinding);

c. Hak menuntut ganti rugi (schade vergoeding);

d. Hak menuntut pemenuhan perikatan dengan ganti rugi;

e. Hakmenuntutpemutusan atau pembatalan perikatan dengan ganti rugi.

14 Ibid, hlm. 21

\section{Perkembangan Gugatan Perbuatan Melawan Hukum}

Hoffman menerangkan bahwa untuk adanya suatu perbuatan melawan hukum harus dipenuhi empat unsur, yaitu: ${ }^{15}$

a. Er moet een daad zijn verricht (harus ada yang melakukan perbuatan);

b. Die daad moet onrechtmatig zijn (perbuatan itu harus melawan hukum);

c. De daad moet aan een ander schade heb bentoege bracht (perbuatan itu harus menimbulkan kerugian pada orang lain);

d. De daad moet aan schuld zijn te wijten (perbuatan itu karena kesalahan yang dapat dicelakakan kepadanya).

Suatu perkembangan yang penting dalam teori hukum adalah mengenai pengertian melawan hukum yang diatur dalam Pasal 1365 Kitab Undang-Undang Hukum Perdata. Semula pengertian melawan hukum hanya diartikan secara sempit yaitu perbuatan yang melanggar undang-undang saja. Akan tetapi, kemudian Hoge Raad dalam kasus yang terkenal Lindenbaum melawan Cohen memperluas pengertian melawan hukum bukan hanya sebagai perbuatan yang melanggar undangundang, tetapi juga setiap perbuatan yang melanggar kepatutan, kehati-hatian, dan kesusilaan dalam hubungan antara sesama warga masyarakat dan terhadap benda orang lain.

Di antara para ahli hukum memang terdapat perbedaan pendapat mengenai keabsahan suatu perjanjian baku. Perjanjian baku adalah perjanjian yang dibuat secara sepihak dan pihak lainnya hanya mempunyai pilihan untuk menerima atau menolak perjanjian tersebut tanpa diberi kesempatan untuk merundingkan isinya. Karena itu perjanjian baku atau standart contract sering disebut juga take it or leave it contract. Perjanjian baku biasanya sudah dicetak dan isinya dibuat seragam seperti karcis-karcis parkir yang dibuat

15 Komariah Emong Sapardjaja, 2012, Ajaran Sifat Melawan Hukum Material Dalam Hukum Pidana Indonesia, Alumni, Bandung, hlm. 34 
oleh tergugat, PT Securindo Pactama Indonesia.

Mengenai keabsahan perjanjian baku terdapat perbedaan pendapat di kalangan para ahli hukum:

a. Sluijter

Perjanjian baku bukan perjanjian, sebab kedudukan pengusaha adalah seperti pembentuk undang-undang swasta.

b. Pitlo

Perjanjian baku adalah perjanjian paksa.

c. Stein

Perjanjian baku dapat diterima sebagai fiksi adanya kemauan dan kepercayaan bahwa para pihak mengikatkan diri pada perjanjian.

d. Asser Rutten

Setiap orang yang menandatangani perjanjian bertanggungjawab terhadap isi dari sebuah perjanjian. Tanda tangan pada formulir perjanjian baku dapat membangkitkan kepercayaan bahwa yang menandatangani mengetahui dan menghendaki isi formulir perjanjian.

Persoalan yang lebih mendasar adalah karena perjanjian baku isinya dibuat secara sepihak, maka perjanjian tersebut cenderung mencantumkan hak dan kewajiban yang tidak seimbang. Seperti adanya klausula eksonerasi atau dalam sistem common law disebut exculpatiry clause. Klausula eksonerasi adalah klausula yang mengalihkan tanggung jawab dari satu pihak ke pihak lainnya, misalnya penjual tidak mau bertanggung jawab atas kualitas barang yang dijualnya, sehingga dicantumkan klausula bahwa barang yang sudah dibeli tidak dapat dikembalikan. Demikian pula pengelola parkir yang tidak mau bertanggung jawab atas kehilangan kendaraan yang di parkir di wilayah yang dikelolanya. Klausula eksonerasi dapat ditemukan pada perjanjian yang dibuat antara pelaku usaha dengan pelaku usaha maupun antara pelaku usaha dengan konsumen.
Undang-Undang Nomor 8 Tahun 1999 tentang Perlindunan Konsumen, berpendirian bahwa perjanjian baku adalah sah, akan tetapi undang-undang ini melarang pencantuman klausula baku yang bersifat berat sebelah dan jika dicantumkan dalam perjanjian, maka klausula baku tersebut adalah batal demi hukum. Pasal 18 ayat (1) Undang-Undang Perlindungan Konsumen menyebutkan klauula baku yang dilarang untuk dicantumkan pada setiap dokumen dan/atau perjanjian, yaitu: ${ }^{16}$

a. Menyatakan pengalihan tanggung jawab pelaku usaha;

b. Menyatakan bahwa pelaku usaha berhak menolak penyerahan kembali barang yang dibeli konsumen;

c. Menyatakan bahwa pelaku usaha berhak menolak penyerahan kembali uang yang dibayarkan atas barang dan/atau jasa yang dibeli oleh konsumen;

d. Menyatakan pemberian kuasa dari konsumen kepada pelaku usaha baik secara langsung maupun tidak langsung untuk melakukan segala tindakan sepihak yang berkaitan dengan barang yang dibeli oleh konsumen secara angsuran;

e. Mengatur perihal pembuktian atas hilangnya kegunaan barang atau pemanfaatan jasa yang dibeli oleh konsumen;

f. Memberi hak kepada pelaku usaha untuk mengurangi manfaat jasa atau mengurangi harta kekayaan konsumen yang menjadi objek jual beli jasa;

g. Menyatakan tunduknya konsumen kepada peraturan yang berupa aturan baru, tambahan, lanjutan dan/atau pengubahan lanjutan yang dibuat sepihak oleh pelaku usaha dalam masa konsumen memanfaatkan jasa yang dibelinya;

h. Menyatakan bahwa konsumen memberi kuasa kepada pelaku usaha

16 Suharnoko, 2014, Hukum Perjanjian, Teori dan Analisa Kasus, Prenada Media, Jakarta, hlm. 126 
untuk pembebanan hak tanggungan, hak gadai atau hak jaminan terhadap barang yang dibeli oleh konsumen secara angsuran.

Selanjutnya dalam Pasal 18 ayat (2) disebutkan bahwa pelaku usaha dilarang mencantumkan klausula baku yang letak dan bentuknya sulit terlihat atau tidak dapat dibaca secara jelas atau yang pengungkapannya sulit dimengerti. Pencantuman klausula seperti ini juga dinyatakan batal demi hukum.

Mengenai hubungan antara wanprestrasi dan perbuatan melawan hukum, M. Yahya Harahap dalam bukunya Segi-Segi Hukum Perjanjian mengatakan bahwa wanprestasi adalah merupakan bentuk khusus dari perbuatan melawan hukum. ${ }^{17}$

Penafsiran secara luas atas pengertian perbuatan melawan hukum juga sejalan dengan perkembangan teori dalam hukum perjanjian bahwa perjanjian harus dibuat dengan iktikad baik yang berarti harus memperhatikan asas kepatutan. Sehingga isi perjanjian yang berat sebelah adalah tidak sesuai dengan kepatutan sehingga klausula yang berat sebelah tersebut dapat dinyatakan batal demi hukum dan tidak mengikat para pihak yang membuat perjanjian.

Dalam hal terjadi wanprestasi atas perjanjian yang objeknya adalah pembayaran sejumlah uang, maka berdasarkan ketentuan Pasal 1250 Kitab Undang-Undang Hukum Perdata yanhg dapat dituntut adalah bunga moratoir atau bunga kelalaian. Bunga moratoir hanya dihitung sejak gugatan didaftarkan di Kepaniteraan Pengadilan Negeri. Besarnya bunga moratoir menurut Stb. 1848 No. 22 jo. 1849 No. 63 adalah enam proses setahun. Yurisprudensi MahkamahAgung berpendapat bahwa bunga menurut undang-undang ini diberlakukan jika para pihak dalam perjanjian tidak menentukan besarnya bunga. ${ }^{18}$

17 M. Yahya Harahap, 2008, Segi-Segi Hukum Perjanjian, Alumni, Bandung, hlm.61

18 Ibid, hlm. 72-73
Perbedaan tersebut sekarang tidak bisa lagi dipertahankan karena tidak semua kewajiban dalam perjanjian lahir dari kesepakatan para pihak dan isi perjanjian tidak selalu disetujui oleh para pihak. Sebagai contoh para pihak yang membuat perjanjian jual beli harus mentaati the Sale of Goods Act 1979 (Undangundang tentang jual beli barang) di mana penjual oleh undang-undang diwajibkan menjamin bahwa barang yang dijual cocok untuk digunakan sesuai tujuannya dan memenuhi standar kualitas yang dibutuhkan atau term of fitness for the purpose and merchantable quality.

Apalagi kewajiban-kewajiban dalam kontrak harus dinilai dengan kriteria objektif dan bukan semata-mata kehendak para pihak yang bersifat subjektif, sehingga tidak relevan lagi pendapat bahwa tort hanya bisa diajukan dalam hal tidak ada hubungan kontraktual antara pihak yang dirugikan dan pihak yang merugikan. Sebaliknya, dalam tort mungkin saja ada unsur kesepakatan menjadi pertimbangan hukum, contohnya seorang pemain sepakbola yang cedera dalam pertandingan sepakbola, mungkin tidak dapat menggugat berdasarkan tort karena dia telah sepakat untuk menanggung risiko cidera.

Selanjutnya dipertanyakan juga perbedaan antara tujuan tort yaitu untuk memberikan perlindungan hukum atas kerugian bagi pribadi dan harta penggugat dan tujuan contract yang melindungi economic interest. Dalam praktik memang dimungkinkan mengajukan gugatan atas dasar tort meskipun salah satu pihak cidera janji atau breach of contract. Di Inggris, apabila kewajiban atas dasar tort melebihi besarnya kewajiban atas dasar breach of contract, maka pengadilan akan enggan untuk menjatuhkan hukuman berdasarkan tort. ${ }^{19}$ Di Amerika Serikat apabila suatu breach of contract juga merupakan tort maka dimungkinkan ganti rugi berupa punitive damages.

19 Ibid, hlm. 25 


\section{PENUTUP}

\section{a. Kesimpulan}

Kitab Undang-Undang Hukum Perdata membedakan antara gugatan wanprestasi yang didasarkan pada hubungan kontraktual antara Penggugat dan Tergugat dan gugatan perbuatan melawan hukum di mana tidak ada hubungan kontraktual antara Penggugat dan Tergugat. Perkembangan dalam praktik putusan-putusan pengadilan menunjukkan bahwa terjadi pergeseran teori tersebut karena hubungan kontraktual antara Penggugat dan Tergugat tidak menghalangi diajukannya gugatan perbuatan melawan hukum.

b. Saran

Demikian pula teori klasik tentang perbedaan antara ganti rugi atas wanprestasi dang anti rugi atas perbuatan melawan hukum tidak lagi berlaku secara mutlak meskipun masih relevan untuk digunakan. Yang perlu diperhatikan apakah kerugian atas kehilangan keuntungan yang diharapkan memang sudah dapat diduga oleh Tergugat dan merupakan akibat langsung dari tidak dipenuhinya perikatan.

\section{DAFTAR PUSTAKA}

Agustina, Rosa, 2008, Perbuatan Melawan Hukum, FH Universitas Indonesia, Jakarta.

Badrulzaman, Mariam Darus, 2006, KUH Perdata Buku III Hukum Perikatan Dengan Penjelasan, Alumni, Bandung.

Badrulzaman, Mariam Darus, et.al., 2011, Kompilasi Hukum Perikatan, PT Citra Aditya Bakti, Bandung

Djojodierdjo, MA Moegni, 2009, Perbuatan Melawan Hukum, Pradnya Paramita, Jakarta

Harahap, M. Yahya, 2008, Segi-Segi Hukum Perjanjian, Alumni, Bandung

Prodjodikoro, Wirjono, 2008, Perbuatan Melanggar Hukum, Sumur Bandung, Bandung

Sapardjaja, Komariah Emong, 2012, Ajaran Sifat Melawan Hukum Material Dalam Hukum Pidana Indonesia, Alumni, Bandung

Setiawan, 2006, Empat Kriteria Perbuatan Melanggar Hukum dan Perkembangannya Dalam Yurisprudensi, Varia Peradilan No. 16, Desember 2006

Setiawan, Rachmat, 2007, Tinjauan Elementer Perbuatan Melawan Hukum, Alumni, Bandung Sjahdeini, Sutan Remy, dkk, 2007, Naskah Akademis Peraturan Perundang-Undangan tentang Perbuatan Melawan Hukum, Badan Pembinaan Hukum Nasional, Departemen Kehakiman RI, Jakarta

Sofwan, Sri Soedewi Masjchoen, 2010, Hukum Perutangan, Seksi Hukum Perdata Fakultas Hukum UGM, Yogyakarta

Subekti, R. dan Tjitrosudibio, 2006, Kitab Undang-Undang Hukum Perdata, PT Pradnya Paramita, Jakarta

Subekti, R., 2008, Hukum Perjanjian, PT Intermassa, Jakarta

Suharnoko, 2014, Hukum Perjanjian, Teori dan Analisa Kasus, Prenada Media, Jakarta Vollmar, H.F.A., 2007, Pengantar Studi Hukum Perdata Jilid II, CV Rajawali, Jakarta 